\title{
The Effect of Patient Age on Standardized, Uptake Value-Hounsfield Unit Values of Male Genitourinery Structures In F-I8 FDG PET/CT
}

\author{
F-I 8 FDG PET/BT'de Erkek Genitoüriner Yapılannda Hasta Yaşının Standart \\ Tutulum Değeri-Hounsfield Ünitesi Değerlerine Etkisi
}

\author{
Berrin Çavuşoğlul, Hatice Durak² \\ IDokuz Eylül University The Institute of Health Sciences Department of Medical Physics, Izmir, Turkey \\ 2Dokuz Eylül University Medical School Department of Nuclear Medicine, Izmir, Turkey
}

\begin{abstract}
Objective: Relation between patient age and Hounsfield Unit (HU),which is the linear attenuation coefficient, and Standardized Uptake Values (SUV) which is the amount of 18F-fluorodeoxyglucose (F-18 FDG) uptake, measured in the areas of interest drawn to prostate, seminal vesicles and testicles in F-18 FDG Positron Emission Tomography/Computed Tomography (PET/CT) images was investigated.

Material and Methods: Mean and maximum SUV and HU values were recorded from the areas of interest $(\mathrm{min} 12 \mathrm{~mm}$ in diameter) which showed FDG uptake in prostate, seminal vesicles and testicles from F-18 FDG PET-CT images of 21 male patients under 40 years without genitourinary cancer. The effect of patient age to SUV and HU values was examined with Pearson correlation test using SPSS program.

Results: There was a negative insignificant correlation between patient age and SUV and HU values for prostate. For seminal vesicles, correlation between patient age and SUV values and $\mathrm{HU}_{\max }$ were positive but insignificant, while correlation with $H U_{\text {mean }}$ was significant $(r=0.459, p=0.00)$. Correlation between patient age and $S U V_{\max }$ and $S U V_{\text {mean }}$ values were significant for testicles ( $r=0.506, p=0.002$ and $r=0.467, p=0.005$, respectively) but the correlation between patient age and $H U_{\text {max }}$ and $H U_{\text {mean }}$ values was not significant.

Conclusion: F-18 FDG uptake in testicles in males increases with age until 40, suggesting an increase in metabolic rate. The significant correlation between age and mean $\mathrm{HU}$ values is probably caused by thickening of the tissue without an increase in glucose metabolism in seminal vesicles. In prostate, the effect of patient age to SUV and HU values was not observed until the age 40. (MIRT 2011;20:104-107)

Key words: PET/CT, SUV, HU, genitourinary system
\end{abstract}

\section{Özet}

Amaç: Bu çalışmada, 18F-Florodeoksiglukoz (18F-FDG) pozitron emisyon tomografi/bilgisayarlı tomografi (PET-BT) görüntülerinde prostat, seminal vezikül ve testislere çizilen ilgi alanlarında ölçülen lineer atenüasyon katsayısı olarak bilinen Hounsfield Ünitesi (HU) değerleri ve aynı bölgede FDG tutulum miktarını veren Standart Tutulum Değeri (SUV) değerleri ile hasta yaşı arasındaki ilişki araştırıldı.

Gereç ve Yöntemler: Çalışma için genitoüriner kanseri olmayan, 40 yaş altındaki 21 erkek hastanın FDG PET-BT görüntülerinden prostat, seminal vezikül ve testislerde FDG tutulumunun bulunduğu ilgi alanlarından, SUV değerleri ve HU değerleri alındı. Minimum 12 mm çapta seçilen alanlarda maksimum ve ortalama SUV ile HU değerleri için 380 veri elde edildi. Hasta yaşının, SUV ile HU değerlerine etkisi SPSS istatistik programı kullanılarak Pearson Korelasyon testi ile incelendi.

Address for Correspondence: Berrin Çavuşoğlu MD, Dokuz Eylül University The Institute of Health Sciences, Department of Medical Physics, İzmir, Turkey GSM: +90 5062356179 E-mail: berrncavusoglu@yahoo.com Received: 17.06.2011 Accepted: 18.10.2011 Molecular Imaging and Radionuclide Therapy, published by Galenos Publishing. 
Bulgular: Elde edilen verilerde prostat için; hasta yaşı ile SUV ve HU değerleri arasında negatif yönde anlamlı olmayan zayıf düzeyde bir korelasyon gözlendi. Seminal vezikül için; hasta yaşı ile SUV değerleri ve $H U_{\max }$ arasında anlamlı olmayan pozitif yönde zayıf düzeyde bir korelasyon varken, yaş ile $\mathrm{HU}_{\text {mean }}$ değeri arasında anlamlı pozitif yönde korelasyon görüldü. Testislerde ise yaş ile $S U V_{\text {max }}$ ve $S U V_{\text {mean }}$ değerleri arasında pozitif yönde anlamlı korelasyon görülürken, hasta yaşı ile $H_{\text {max }}$ ve $H U_{\text {mean }}$ değerleri arasında sırasıyla negatif ve pozitif yönde anlamlı olmayan zayıf düzeyde korelasyon bulundu.

Sonuç: PET/BT çekiminde erkek hastalarda FDG tutulumunun testislerde yaş ile doğru orantılı olması, yaş ilerledikçe metabolik hızda artış olduğunu göstermektedir. Seminal vezikülde, yaş ile $\mathrm{HU}_{\text {mean }}$ değeri arasındaki anlamlı korelasyon muhtemelen doku kalınlaşmasından kaynaklanmaktadır. 40 yaşına kadar prostatta, hasta yaşının SUV ile HU değerlerine herhangi bir etkisi gözlenmemiştir. (MIRT 2011,20:104-107)

Anahtar kelimeler: PET/BT, SUV, HU, genitouriner sistem

\section{Introduction}

Integrated Positron Emission Tomography/Computed Tomography (PET/CT) allows morphological and functional imaging in a single imaging process by combining PET and CT in a single device and is an important diagnostic imaging tool for the identification, localization and characterization of different group of malignancies (1).

Determination of the characteristics of the lesions can be made by examining the Standardized Uptake Value (SUV) and Hounsfield Unit (HU) values in integrated PET/CT systems. It is important to know the value of the normal tissues for appropriate evaluation of pathology. Uptake of F 18 Fluorodeoxyglucose (F-18 FDG) is frequently observed in varying degrees in the male genitourinary structures and sometimes physiological uptake is confused with pathology. Physiological uptake and also the tissue density in genitourinary structures may be expected to change with age, associated to metabolic and histological changes due to maturing and aging. (2) We aimed to investigate the relation between patient age and Hounsfield Unit (HU) and SUV values measured in the areas of interest drawn to prostate, seminal vesicles and testicles, where sometimes high uptake is observed in F18 FDG PET/CT images.

\section{Materials and Methods}

Twenty two male patients under 40 years of age who has undergone F-18 FDG PET/CT without genitourinary cancer or any previously reported abnormal findings in the genitourinary system were selected from the database. The age range was 5-37 and the mean age was 25.0 \pm 8.1 . In all patients, PET/CT was performed one hour after the injection of 7 - 15 mCi F-18 FDG using Philips Gemini TF 16. The patients fasted at least $4 \mathrm{~h}$ prior to intravenous injection of F-18. No patients had diabetes or blood glucose levels over $140 \mathrm{mg} / \mathrm{dL}$ PET was performed as 1.5 minutes per bed position from the base of the head to the mid thigh. CT parameters were 50- $80 \mathrm{mAs} 120 \mathrm{kVp}, 5$ $\mathrm{mm}$ slices at $39 \mathrm{~mm} / \mathrm{sec}$ in $512 \times 512$ matrix. Primary diagnosis of patients were as follows: NonHodgkin's lymphoma $(n=2)$, osteosarcoma $(n=1)$, lymphoblastic lymphoma $(n=1)$, sarcomatoid carcinoma $(n=1)$, mixed germ cell tumor $(n=1)$, germ cell tumor $(n=1)$, anaplastic large cell lymphoma $(n=2)$, leimyosarcoma $(n=1)$, Hodgkin's lymphoma $(n=3)$, metastatic tumor $(n=1)$, hamartoma $(n=1)$, paraneoplastic syndrome $(n=1)$, soft tissue sarcoma $(n=1)$, stomach cancer $(n=1)$, malign mesenchymal tumor $(n=1)$, Kaposi's sarcoma $(n=1)$ and diffuse large $B$ cell lymphoma $(n=1)$.

SUV and HU values were recorded from the areas, which showed FDG uptake in prostate, seminal vesicles and testicles using the transaxial slices of fused F-18 FDG PET-CT images (Figure 1). Maximum and mean SUV and $\mathrm{HU}$ values from the regions of interests with a minimum of $12 \mathrm{~mm}$ in diameter were obtained (3). If one of the seminal vesicles or testicles were not visualized enough to place a ROI, SUV and $\mathrm{HU}$ values were taken from only one side in some patients (for seminal vesicles bilateral in 19 patients, unilateral 2 in patients; for testicles bilateral in 12 patients, unilateral in 10 patients).

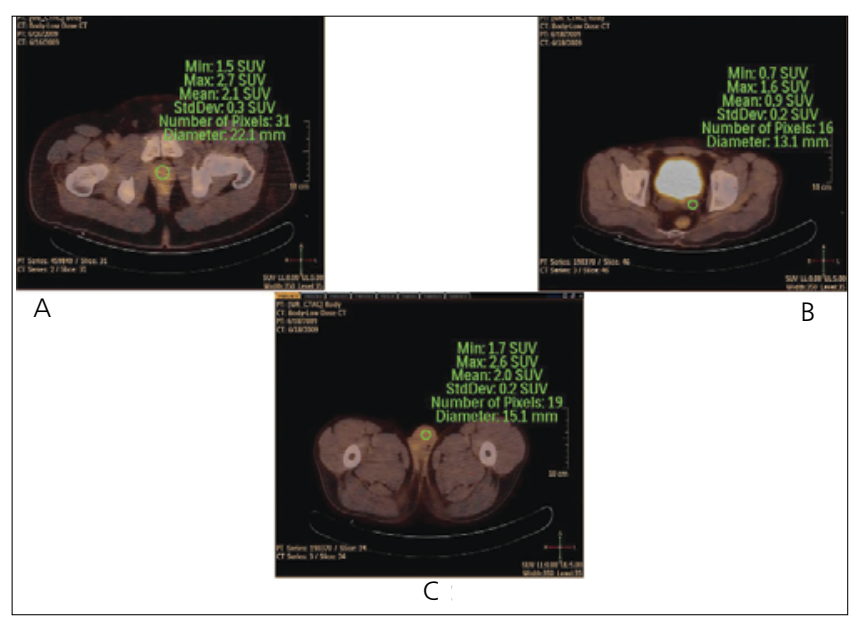

Figure 1. Regions of Interests drawn on prostate (A), seminal vesicles (B) and testicles (C) 
Mean and standard deviation values were calculated for maximum and mean SUV and HU values. The effect of patient age on SUV and HU values was assessed with Pearson correlation test using SPSS program. $p \leq 0.05$ was considered significant.

\section{Results}

Mean patient age, mean $S U V_{\max }$ and $S U V_{\text {mean, }}$ mean $\mathrm{HU}_{\text {max }}$ and $\mathrm{HU}_{\text {mean }}$ values obtained from the areas of interest are shown in the Table 1. Though we did not perform any statistical analysis regarding the SUV and $\mathrm{HU}$ values to compare the organs, SUV $\max$ was higher in seminal vesicles compared to testicles and prostate, but there was a wide standard deviation. Both $\mathrm{HU}_{\max }$ and $\mathrm{HU}_{\text {mean }}$ were higher in prostate gland compared to testicles and seminal vesicles. Correlations between patient age and $S U V_{\text {max }}, S U V_{\text {mean }}, H U_{\text {max }}, H U_{\text {mean }}$ values are shown in Table 2.

There was a negative insignificant correlation between patient age and SUV and HU values for prostate. For seminal vesicles, correlation between patient age and
HUmean was significant $(r=0.459, p=0.00)$ (Figure 2). Correlation between patient age and $S U V_{\max }$ and SUV $V_{\text {mean }}$ values were significant for testicles $(r=0.506$, $p=0.002$ and $r=0.467, p=0.005$, respectively) (Figure 3).

\section{Discussion}

Our patient selection involved patients from puberty to up to age 40 to reveal the effect of maturation of the organs on metabolic and tissue density parameters. Therefore, we did not include the effect of advanced age, which may be also studied by others as long as there are normal patients available in patient database. Occult prostate carcinoma may be present in the elderly and it is not possible to evaluate any $18 \mathrm{~F}$ FDG uptake as physiologic or pathologic unless a carcinoma is excluded by biopsy (4). In prostate gland, we did not observe any significant effect of patient age to SUV and HU values. It seems that the metabolic activity and tissue density of the prostate gland do not significantly change from puberty to middle age. Jadvar et al (5) also reached this conclusion.. They concluded their aforementioned study

Table 1. The standard deviation and mean values of patient age, SUV max, SUV mean, $H U_{\text {max }}$ and $H U_{\text {mean }}$ in different structures

\begin{tabular}{lccccc}
\hline & Patient Age Mean \pm SD & SUV $_{\text {max }}$ Mean \pm SD & SUV mean Mean \pm SD & HU $_{\text {max }}$ Mean \pm SD & HUmean Mean \pm SD \\
\hline Prostate (21 ROls) & $26.0 \pm 7.0$ & $2.8 \pm 0.7$ & $2.0 \pm 0.5$ & $142.7 \pm 75.8$ & $43.2 \pm 15.0$ \\
Seminal vesicles (40 ROls) & $26.4 \pm 6.8$ & $4.0 \pm 9.8$ & $1.7 \pm 2.0$ & $82.0 \pm 32.9$ & $13.5 \pm 11.3$ \\
Testicles (34 ROls) & $25.1 \pm 8.5$ & $3.2 \pm 0.9$ & $2.6 \pm 0.9$ & $54.4 \pm 13.9$ & $19.6 \pm 13.8$
\end{tabular}

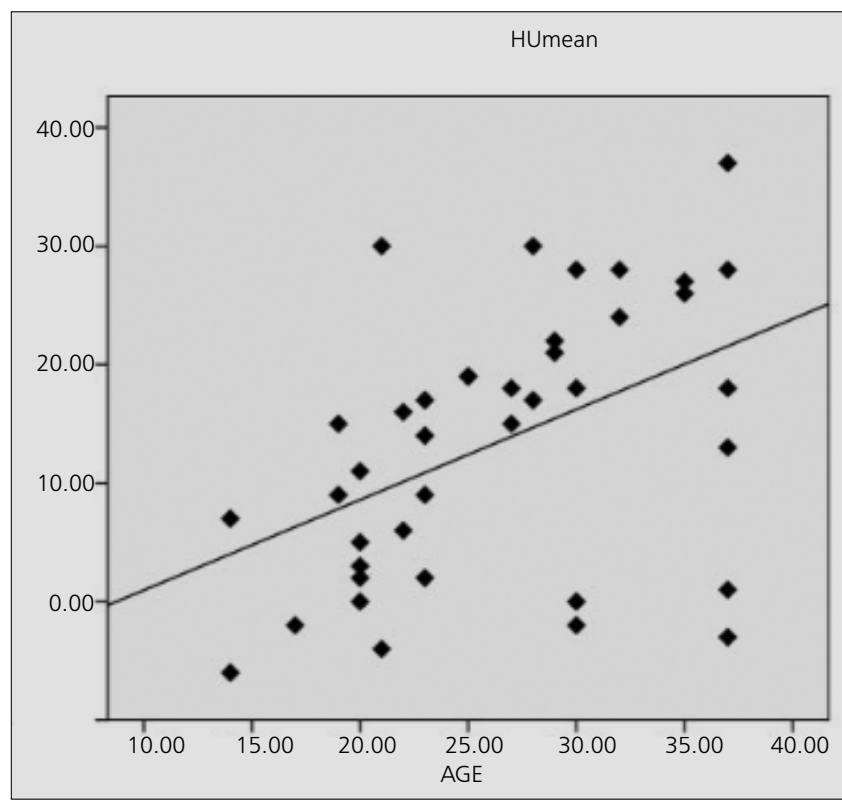

Figure 2. Distribution of HUmean values according to patient age in seminal vesicles and the linear fit curve $(p=0.003)$

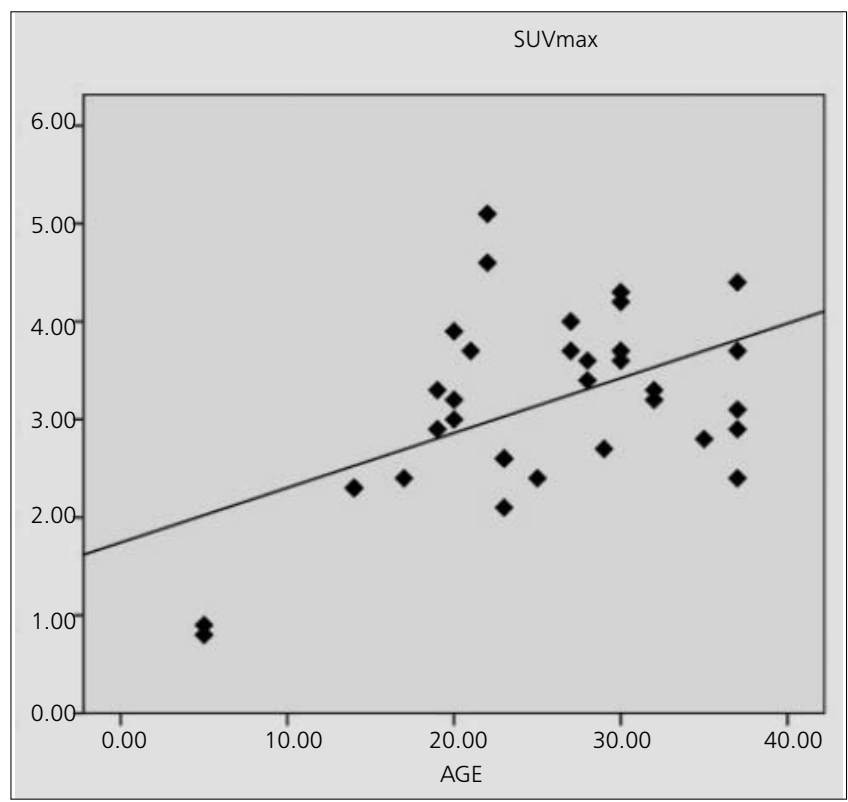

Figure 3. Distribution of SUVmax values according to patient age in testicles and the linear fit curve $(p=0.002)$ 
stating that the normal prostate size increases with age, it does not significantly affect metabolism of the gland and CT density.

The significant correlation between age and mean HU values in seminal vesicles is probably caused by thickening of the tissue without an increase in glucose metabolism in seminal vesicles. In Magnetic Resonance TI weighted images, normal seminal vesicle signal intensity was shown to be similar to that of muscle or bladder. Dihydrotestosterone and testosterone propionate are shown to increase the weight and the collagen content of the seminal vesicles in rats (6). Our group consists of men between ages 14 and 37, so development of the seminal vesicles may be reflected by the increase in $\mathrm{HU}$ values.

We found that F-18 FDG uptake in testicles in males increased significantly with age until 40 suggesting an increase in the glucose metabolic rate. A strong positive correlation between F-18 FDG uptake in the testis and age was shown in pediatric age group, between 9 to 17 years of age. The correlation coefficient was found as 0.406 in 42 PET-CT studies (7). Actually, the curve in Figure 3 may be biexponential, showing a fast increase in $S U V_{\max }$ in pediatric ages followed by a mild slope after adolescence which was similarly reported in the literature that testicular metabolic activity demonstrated an increasing trend until the age of 35 with a plateau afterwards until the age of 65 years (8). An increase in testicular volume with age from birth to 25 years was reported. After age 25 , testicular volume started to decline and testicular volume was positively correlated with age $(r=0.67)(8)$. According to Yang et al (9) testicular volume rapidly increases during puberty and peaks at age 30 years. Though we had a few pediatric patients, we have seen a significant correlation. We did not calculate the testicular volumes, but it seems that partial volume may have an

Table 2. Correlation analysis between patient age and $S U V_{\max }$, SUV mean, $\mathrm{HU}_{\text {max }}$ and $\mathrm{HU}_{\text {mean }}$ values

\begin{tabular}{|c|c|c|c|}
\hline & & $r$ & $\mathbf{p}$ \\
\hline \multirow[t]{4}{*}{ PROSTATE } & Patient Age - SUV $\max$ & -0.140 & 0.545 \\
\hline & Patient Age - SUV mean & -0.120 & 0.604 \\
\hline & Patient Age - HUmax & -0.210 & 0.361 \\
\hline & Patient Age - $H U_{\text {mean }}$ & -0.314 & 0.166 \\
\hline \multirow[t]{3}{*}{$\begin{array}{l}\text { SEMINAL } \\
\text { VESICLES }\end{array}$} & $\begin{array}{l}\text { Patient Age - SUV max } \\
\text { Patient Age - SUV }\end{array}$ & $\begin{array}{l}0.111 \\
0.093\end{array}$ & $\begin{array}{l}0.495 \\
0.566\end{array}$ \\
\hline & Patient Age - $\mathrm{H} U_{\max }$ & 0.066 & 0.685 \\
\hline & Patient Age - $\mathrm{HU}_{\text {mean }}$ & $\left.0.459{ }^{* *}\right)$ & $0.003(* *)$ \\
\hline \multirow[t]{4}{*}{ TESTICLES } & Patient Age - SUV $\max$ & $0.506(* *)$ & $0.002\left(^{* *}\right)$ \\
\hline & Patient Age - SUV mean & $0.467\left({ }^{\star \star}\right)$ & $\left.0.005^{* *}\right)$ \\
\hline & Patient Age - $H U_{\max }$ & -0.214 & 0.225 \\
\hline & Patient Age - HUmean & 0.219 & 0.214 \\
\hline
\end{tabular}

influence on the SUV values causing an overestimation of the correlation with age. Kitajima K et al reported the SUV value as $2.81 \pm 0.43$ between the ages $30-39$ years (10). Our mean $S U V_{\max }(3.2 \pm 0.9)$ was a little bit higher perhaps due to the younger age of the patients. It has been reported by Amrolia et al. (11) that Leydig cells which produce testosterone take up glucose by a transport system that is similar to the facilitated-diffusion system of glucose uptake in other mammalian cells. Therefore, increased FDG uptake in the testes of the younger man and reduction in elderly may be caused by the changing of the number and production ability of Leydig cells (11).

In conclusion, we observed that F-18 FDG uptake in testicles in male increases with age until 40 suggesting an increase in metabolic rate. It seems that in seminal vesicles, there is an increase in tissue density without an increase in glucose metabolism. In prostate, the effect of patient age to SUV and HU values was not observed until the age 40.

\section{References}

1. Schillaci O, Simonetti G. Fusion imaging in nuclear medicineapplications of dual-modality systems in oncology. Cancer Biother Radiopharm 2004;19:1-10.

2. Srinivasan N, Aruldhas MM, Govindarajulu P. Sex Steroid-induced Changes in Collagen of the Prostate and Seminal Vesicle of Rats. J Androl 1986;55-58.

3. Boellaard R, O'Doherty MJ, Weber WA, Mottaghy FM, Lonsdale MN, Stroobants SG, Oyen WJ, Kotzerke J, Hoekstra OS, Pruim J, Marsden PK, Tatsch K, Hoekstra CJ, Visser EP, Arends B, Verzijlbergen FJ, Zijlstra JM, Comans EF, Lammertsma AA, Paans AM, Willemsen AT, Beyer T, Bockisch A, Schaefer-Prokop C, Delbeke D, Baum RP, Chiti A, Krause BJ. FDG PET and PET/CT: EANM procedure guidelines for tumour PET imaging: version 1.0. Eur J Nucl Med Mol Imaging 2010:37:181-200.

4. Han EJ, H O J, Choi WH, Yoo IR, Chung SK. Significance of incidental focal uptake in prostate on 18-fluoro-2-deoxyglucose positron emission tomography $\mathrm{CT}$ images. $\mathrm{Br} J$ Radiol 2010;83:915-920.

5. Jadvar H, Ye W, Groshen S, Conti PS. [F-18]-fl uorodeoxyglucose PET-CT of the normal prostate gland. Ann Nucl Med 2008; 22:787-793.

6. King $B F$, Williamson $B$, Hattery RP, Hartman GW, Lieber MM, Berquist TH. Seminal vesicle imaging. Radio Graphics 1989:9:4:653-676.

7. Goethals I, Vriendt C, Hoste P, Smeets P, Ham H. Normal uptake of F-18 FDG in the testis as assessed by PET/CT in a pediatric study population. Ann Nucl Med 2009;23:817-820.

8. Well $D$, Yang $H$, Houseni $M$, Iruvuri $S$, Alzeair $S$, Sansovini M, Wintering N, Alavi A, Torigian DA. Age-related structural and metabolic changes in the pelvic reproductive end organs. Semin Nucl Med 2007;37:173-184.

9. Yang $H$, Chryssikos T, Houseni M, Alzeair S, Sansovini M, Iruvuri S, Torigian DA, Zhuang H, Dadparvar S, Basu S, Alavi A. The effects of aging on testicular volume and glucose metabolism: an investigation with ultrasonography and FDG-PET. Mol Imaging Biol 2011;13:391-398.

10. Kitajima K, Nakamoto $Y$, Senda $M$, Onishi $Y$, Okizuka $H$, Sugimura K. Normal uptake of 18F-FDG in the testis: an assessment by PET/CT. Ann Nucl Med 2007;21:405-410.

11. Amrolia P, Sullivan MHF, Garside D, Baldwin SA, Cooke BA. An investigation of glucose uptake in relation to steroidogenesisin rat testis and tumor Leydig cells. Biochem J 1988;249:925-928. 